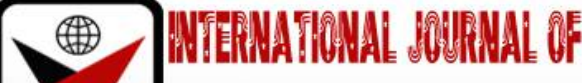

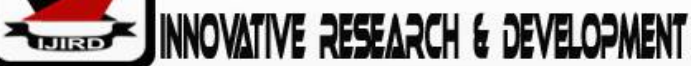

ISSN 2278-0211 (Online)

\section{Information Technology and Global Supply Chain Management}

\author{
Obialor, Donatus Chukwemeka \\ Lecturer, Department of Business Management, \\ University of Uyo, Uyo, Nigeria
}

\begin{abstract}
:
The dynamic business environment today has continued to force business to rise beyond their localized business environment and go global, instigated by the fast-evolving Information Technology (IT) platforms. The study was conducted to examine the impact of the relationship between Information Technology and Global Supply Chain Management. The study adopted the descriptive survey design. With a population size of 190, the Taro Yammeh formula was used to determine a sample size of 150. The coefficient of determination was employed to test the reliability of the test instrument and the Pearson Product Moment Correlation Coefficient statistical tool was used in testing the hypothesis at 0.05 level of significance. The findings revealed that Information Technology have a significant impact on global Supply Chain Management with a correlation coefficient of -. 503 and p-value of .309. The researcher concluded the study conclude that IT is the major driver of GSCM, hence IT has remained crucial to the performance of GSCM and global businesses has been fueled and enabled by IT which has redefined all aspects of business today, hence enhances inter-organizational relationships.
\end{abstract}

Keywords: Global supply chain management, supply chain, information technology, ERP, SC drivers

\section{Introduction}

The dynamic business environment today has continued to force businesses to rise beyond their localized business environment and go global, instigated by the fast-evolving Information Technology (IT) platforms. To get competitive advantages, global Supply Chain Management (GSCM) is getting infused with information Technology (IT). It helps to achieve efficiency in terms of costs and time. Akhadian (2010), called Global Supply Chain Management as “a dynamic worldwide network created among different worldwide companies producing, handling and distributing specific goods and / or products".

Throughout the globe, Supply Chain Management has been practiced. It helps to delivery time reduction and performance enhancement, greater customer satisfaction (Milgate 2001).

Quesada and Meneses (2010) highlighted how a supply chain works. They also identified the critical factors affecting Supply Chain Management. Quesada and Meneses states the following factors to include, environmental uncertainty, information technology, supply chain management performance, business management and customer satisfaction. Rahul (2005) called the global supply chain as management of network of interconnected business.

As per him supply chain management helps to achieve the strategic fit. Lalonde (1996) called it as a way to create high values for customers. Chiappe and Herrero (1997) maintain that Supply Chain Management includes how a company share information and take action in order to ensure the best flow of product from raw material to end user.

\subsection{Statement of the Problem}

Increasingly, businesses are becoming more efficient, transparent and digitally connected including our customers due to improved supply chain delivery and response time. The study therefore is faced with the challenges of investigating the role of Information Technology on Global Supply Chain Management.

\subsection{Objectives of the Study}

The objective of this study is to examine the interrelationship between Information Technology and Global Supply Chain Management. Thus, the following specific objective is to:

- Assess the impact of Information Technology on key supply chain drivers.

\subsection{Research Question}

- What is the impact of Information Technology on key supply chain drivers? 


\subsection{Research Hypothesis}

- Information Technology have no significant impact on key supply chain drivers.

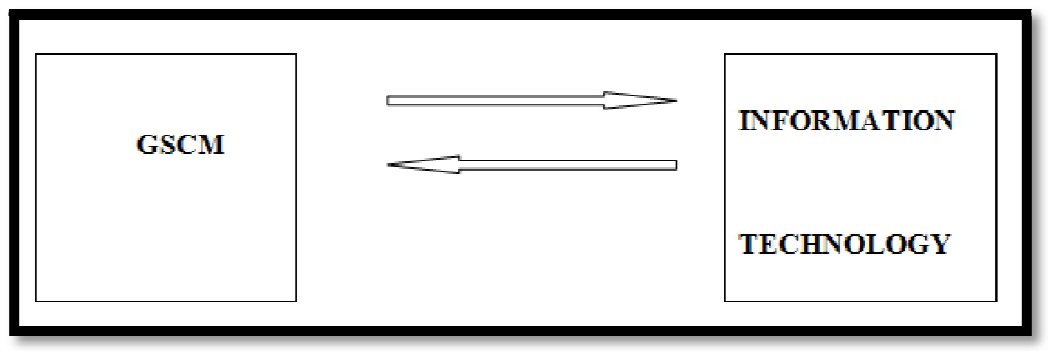

Figure 1: Review of Related Literature

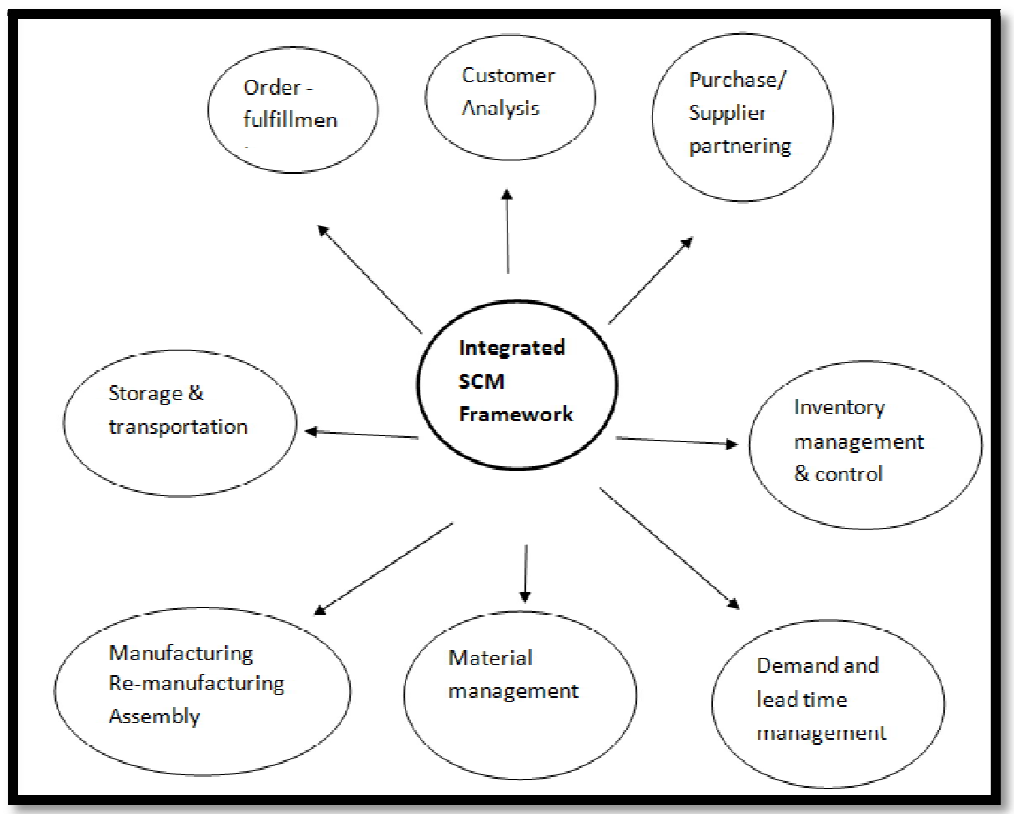

Figure 2: Integrated Supply Chain Management Framework Source: GSC Council, http://wwwsmartsheet.com.ng/scal

\subsection{Concept of Global Supply Chain Management}

Milgate (2001) maintains that the concept of supply chain management on the basis of two ideas. The first is that practically every product that reaches an end user represents the cumulative effort of multiple organizations. The second idea is that while supply chain has existed for a long time, most organizations have only paid attention to what was happening within their 'Four Walls'.

The organizations that make up the supply chain are 'Linked' together through physical flows and information flows.

- Physical flows: Involves the transportation, movement, and storage of goods and materials.

- Information flows: Allow the various supply chain partners to coordinate their long-term plans, and to control the day-to-day flow of goods and materials up and down the supply chain.

Wowak, Craighead, Ketchen \& Hult (2013) maintained that the purpose of SCM is to make inventory readily available in customer facing positions to fulfill demand (which will help the organization reduce waste, drive out costs and achieve efficiencies in the supply chain).

The goal of SCM according to Wowak etal. (2013) is to achieve efficient fulfillment. Global Supply Chain Management (GSCM) goal also is to increase profit leverage (firms' value) because they help control and reduce supply chain costs. The third is that it increases cash flow (firms value supply chain manages because they speed up product flows to customers).

\subsection{Benefits of IT to GSCM}

- Greater Transparency: Increasingly, businesses have become digitally connected including our customers. Transparency will increase with the advancement of technology. It will also improve the pace significantly.

- Greater Efficiency and Faster Processes: With the advancement of the technology, warehouse and transport systems are becoming efficient. It also enables labour management and resource monitoring.

- Communication: Improved communication leads to improved operation. Development and understanding become wider. Software leads to effective communication among organizations and with the clients.

- Technology has evolved, enabling people to tie their business together: Combined processes altogether helps to save time and reduce the risks associated with the production. Manual mistakes can be easily rectified. Integration of all activities makes the business advantageous. 


\subsection{Role of IT on Key Supply Chain Drivers in GSCM}

Information is one of the key elements of the supply chain. It helps to make the supply chain visible to a manager (Akhadian, 2015).

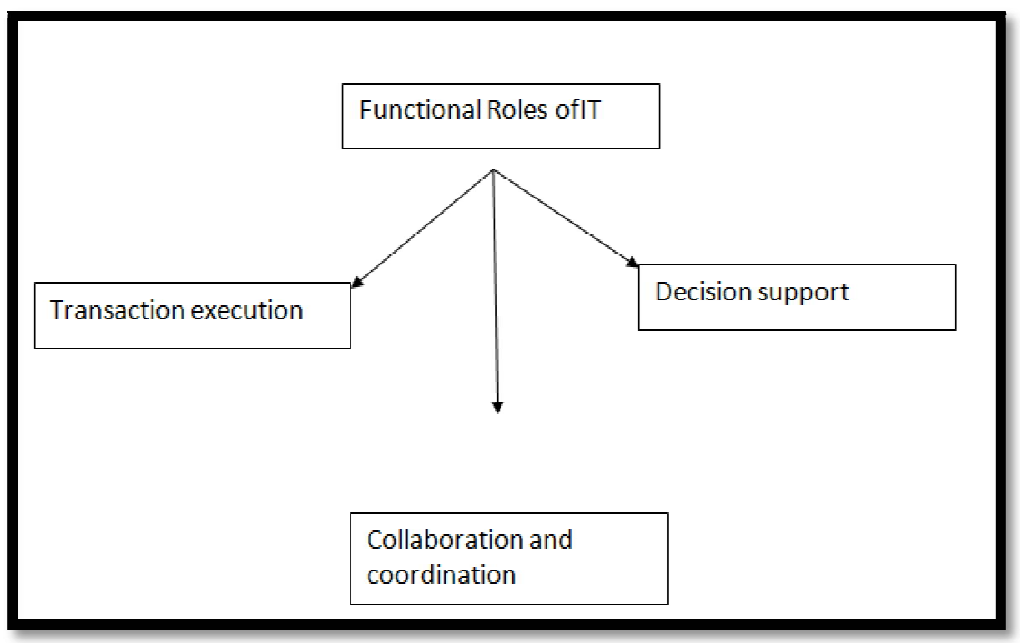

Figure 3: Functional Roles of IT

Source: Akhadian (2015) Functional Roles of IT

As per Akhadian (2015), the introduction of IT in Supply Chain Management helps to reduce cost in information, operation flow. It provides a supporting role in the collaborations of all activities in the supply chain. It acts as a decision support system for taking analytical and managerial decisions.

\subsection{Objectives}

- $\quad$ Providing information - (availability and visibility)

- Enabling single point of contact of data

- Allowing decisions based on total supply chain information.

- Enabling collaboration with supply chain partners

\subsubsection{Supply Chain Management}

According to Rahul (2005), effective supply chain helps to achieve customer value and sustainable competitive advantage. Sunil and Peter (2005), called it as an interconnection among three or more companies by one or more of the upstream and downstream flows of the product, services, finances and information from a source to a customer.

\subsection{Information Technology (IT) and Middlemen Efficiency}

Information is one of the most important enablers of the supply chain in modern complex world of global businesses. Global businesses have been fueled and enabled by the IT which has redefined all aspects of business today (Handfield and Nicholas, 2002).

The advantage will include supply contracts via internet, distribution of strategies, outsourcing and procurement (Simchi-Levi, Kaminsky and Simchi-Levi 2003). The use of IT in global supply chain enhances inter-organizational relationships (Humphreys, Lai and Sculli: 2001).

Demand planning, forecasting and global procurement managements can be efficiently practiced through supply chain. The availability of the sophisticated systems has further enabled companies to implement good and cost-effective manufacturing practices. Various ERP modules combined with additional specific applications as required.

ERP has enabled companies to manage their business processes in different markets. On-line purchase has impacted the way supply chains are organized and markets are driven. Customer behavior and preferences are changing as on-line marketing is establishing a one to one contact with the customer and can offer a personalized experience (Humphrey et al 2001).

Any person sitting in any corner of the Globe can purchase a product online at the click of a button (Tim 2007). 


\section{Impact of It on GSCM}

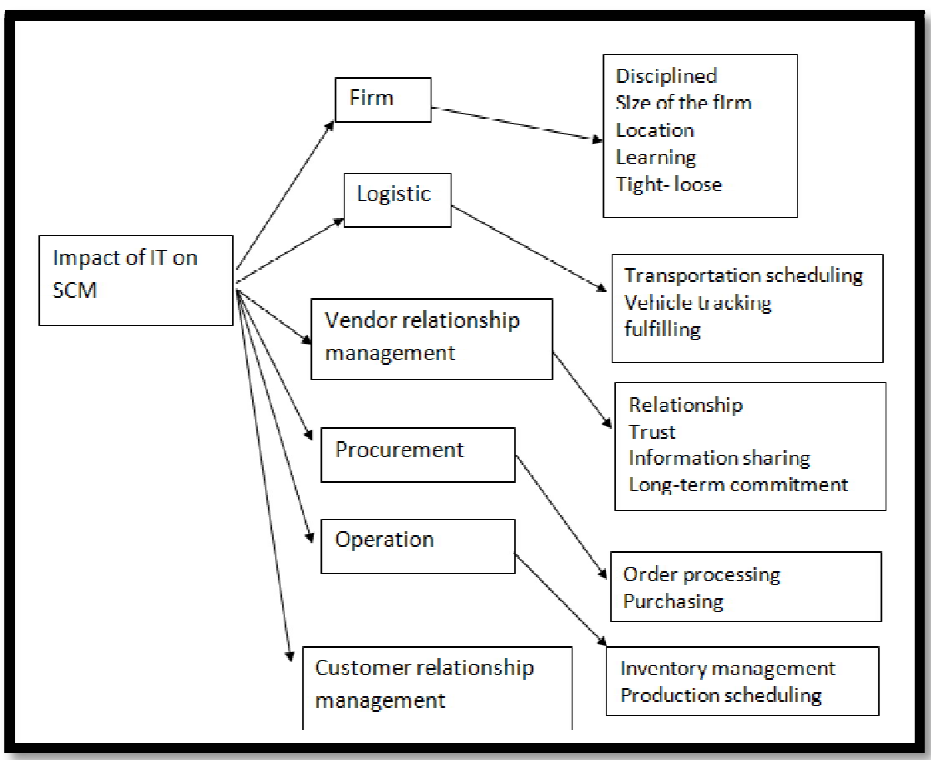

Figure 4: Impact of It on GSCM

Source: Adopted from Fasanghari and Kamal (2008) Assessing the impact of IT on SCM

\subsection{Key Related Factors Driving Global Supply Chain Management}

Supply Chain Capabilities are guided by the decisions you make regarding the five Supply Chain Drivers. Each of these drivers can be developed and managed to emphasize responsiveness or efficiency depending on changing business requirements.

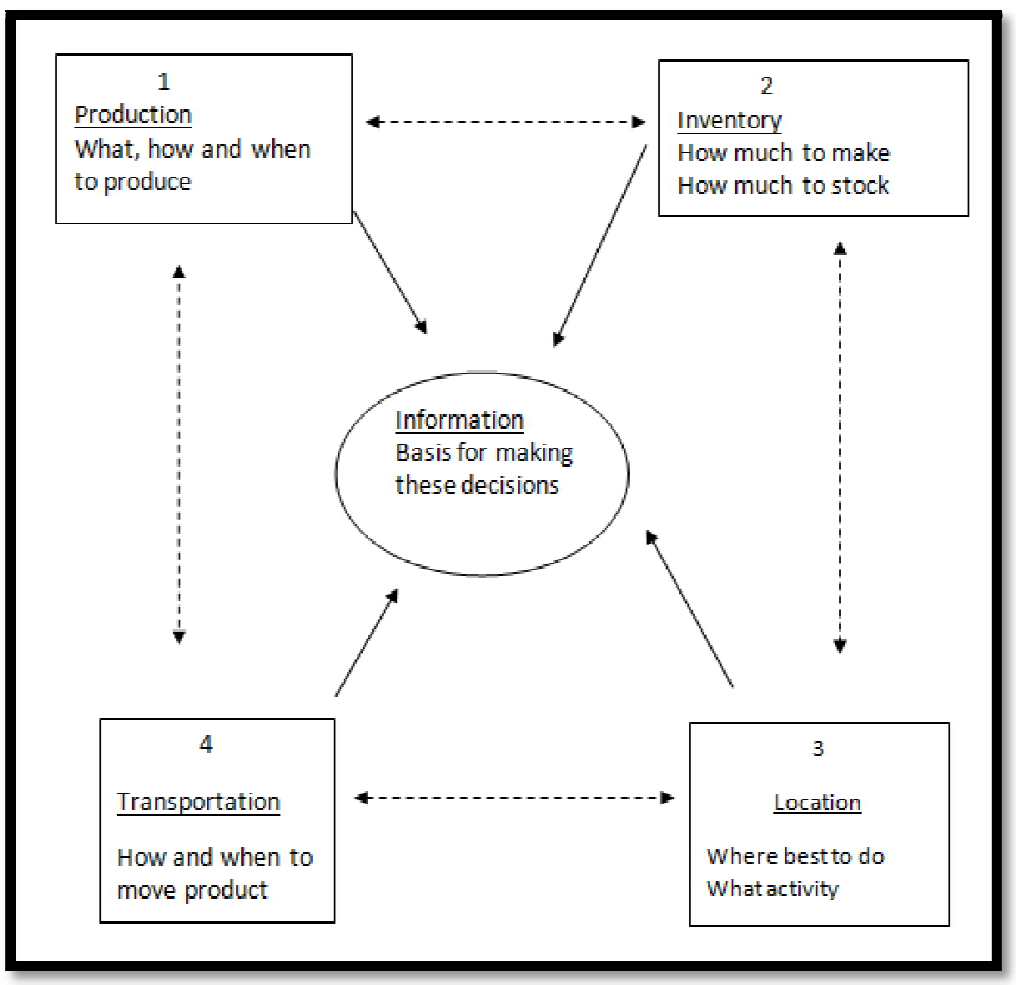

Figure 5: Key Related Factors Driving Gscm

Source: Online Sc Design and Simulation Showing Supply Chain Drivers. Adopted from blog.scmglobe-com/?p=422

\subsubsection{Production}

For factories where lot of excess capacity is present, this factor is very important. With wider array of product, it helps to achieve flexible manufacturing system. It helps to achieve smaller delivery time.

\subsubsection{Inventory}

Inventory helps to gain additional responsiveness throughproper stock. It provides the capacity to stock items those can't be sold easily as well as frequently. Proper inventory control helps to achieve economies of scale and cost savings. 
Using SCM Globe you simulate decisions about inventory by setting product production and product demand levels at facilities and by defining on-hand amounts for different products at facilities throughout the supply chain.

\subsubsection{Location}

Location decisions are very crucial. It directly related with financial aspects, employment and distribution pattern. Relocation also affects a production severely. It may lead to stoppage of the production, many inconveniences to the normal operations. Many general like - availability of labor, raw materials, necessary modes of transportations affect the location decisions. Other specific factors like economic stability, cultural factors also influence this. An example of this is the way Dell serves large geographical markets from only a few central locations that perform a wide range of activities.

\subsubsection{Transportation}

Responsiveness can be achieved by a transportation mode. Fast transportation helps to deliver their products often within 24 hours. FedEx and UPS are two companies that can provide very responsive transportation services. Now, Amazon is expanding and operating its own transportation services in high volume markets.

\subsubsection{Information}

Information is a key supply chain driver because it serves as the glue that allows the other supply chain drivers to work together. It provides the foundation on which supply chain processes execute transactions and managers make decisions. Without information, a manager cannot know what customers want, how much inventory is in stock, and when more products should be produced or shipped.

\begin{tabular}{|c|c|c|c|}
\hline $\mathbf{S} / \mathbf{n}$ & Supply Chain Drivers & Responsiveness & Efficiency \\
\hline 1 & Production & $\begin{array}{c}\text { Excess capacity } \\
\text { Flexible manufacturing } \\
\text { Many smaller plants }\end{array}$ & $\begin{array}{l}\text { Little excess capacity } \\
\text { Narrow focus } \\
\text { Few central plants }\end{array}$ \\
\hline 2 & Inventory & $\begin{array}{l}\text { High inventory level } \\
\text { Wide range of items }\end{array}$ & $\begin{array}{c}\text { Low inventory level } \\
\text { Fewer items }\end{array}$ \\
\hline & Location & Many locations close to customers & Few central locations serve wide areas. \\
\hline 4 & Transportation & $\begin{array}{c}\text { Frequent shipment } \\
\text { Fast and flexible modes }\end{array}$ & $\begin{array}{c}\text { Fewer large shipments } \\
\text { lower and cheaper modes }\end{array}$ \\
\hline 5 & Information & $\begin{array}{l}\text { Collect and share timely and } \\
\text { accurate data }\end{array}$ & $\begin{array}{l}\text { Cost of information drops while other } \\
\text { costs rise. }\end{array}$ \\
\hline
\end{tabular}

Table 1: Supply Chain Drivers Degree of Responsiveness or Efficiency

Source: Online SC Design \& Simulation.Blog.Scmglobe.Com/?P=422

\section{Methodology}

The study adopted the descriptive survey design and a simple random sampling technique. The sources of data were basically from primary and secondary sources. With a population size of 190, the Taro Yamane formula was used to determine a sample size of 150 .

$$
\mathrm{n}=\frac{\mathrm{N}}{1+\mathrm{N}(\mathrm{e})^{2}}
$$

where $\mathrm{n}=$ sample size, $\mathrm{N}=$ population size, $\mathrm{e}=$ error margin

The reliability of the measuring instrument is tested using the coefficient of determination, $\mathrm{r}^{2} \times 100$ which represents the amount of variations both variables share. Likert scale technique was used for data analysis. Using: Strongly agree (5points), Agree (4points), Undecided (3points), Disagree (2points), Strongly disagree- (1point).

The study administered 150 copies of questionnaire to the respondents out of which was correctly filled and returned. Pearson product-moment correlation coefficient statistical tool was used to test the research hypothesis generated for the study with the use of software package for social science (SPSS) version 23. The formula for correlation is as follows:

$$
r=\frac{n \sum x y-\sum x \sum y}{\sqrt{\left[n \sum x^{2}-\sum(x)^{2}\right]\left[n \sum y^{2}-\sum(y)\right]^{2}}}
$$

Degree of freedom $(\mathrm{df})=\mathrm{n}-2$

Decision rule: reject $\mathrm{H}_{\mathrm{o}}$ if $\mathrm{t}_{\mathrm{cal}}>\mathrm{t}_{\mathrm{tab}}$ observed at $5 \%$ level of significance 


\section{Data Presentation and Analysis}

\begin{tabular}{|c|c|c|c|c|c|c|c|c|}
\hline $\mathbf{S} / \mathbf{N}$ & QUESTION ON GSCM & SA & $\mathbf{A}$ & UD & D & SD & TOTAL & $\mathbf{X}$ \\
\hline 1 & $\begin{array}{l}\text { High levels of responsiveness can be achieved when } \\
\text { companies collect and share accurate and timely data } \\
\text { generated by the operations of the other four drivers. }\end{array}$ & 45 & 38 & 24 & 27 & 20 & 154 & 34.9 \\
\hline 2 & $\begin{array}{l}\text { SCMis the active management of supply Chain activities to } \\
\text { maximize customer value and achieve a sustainable } \\
\text { competitive advantage. }\end{array}$ & 29 & 33 & 5 & 47 & 40 & 154 & 28.4 \\
\hline 3 & $\begin{array}{l}\text { Companies resort to supply chain practices to improve } \\
\text { their performance }\end{array}$ & 40 & 57 & 9 & 22 & 26 & 154 & 33.7 \\
\hline 4 & The goal of SCM is to achieve efficient fulfillment & 51 & 32 & 11 & 28 & 32 & 154 & 33.6 \\
\hline 5 & $\begin{array}{l}\text { Production as a driver of SCM can be made very responsive } \\
\text { by building factories that have a lot of excess capacity and } \\
\text { use flexible manufacturing techniques to produce a wide } \\
\text { range of items. }\end{array}$ & 16 & 29 & 25 & 56 & 28 & 154 & 27.4 \\
\hline 6 & $\begin{array}{l}\text { Integrating processes across your operations saves time } \\
\text { and minimizes risk factors such as man-made manual } \\
\text { mistakes }\end{array}$ & 39 & 13 & 8 & 41 & 53 & 154 & 27.1 \\
\hline 7 & $\begin{array}{l}\text { Supply Chain Capabilities are guided by the decisions you } \\
\text { make regarding the five Supply Chain Drivers. }\end{array}$ & 21 & 10 & 5 & 66 & 52 & 154 & 22.9 \\
\hline 8 & $\begin{array}{l}\text { IT allows all the actors in the supply chain to communicate } \\
\text { among each other. }\end{array}$ & 12 & 14 & 13 & 47 & 68 & 154 & 21.1 \\
\hline 9 & $\begin{array}{l}\text { On-line purchase has impacted the way supply chains are } \\
\text { organized and markets are driven. }\end{array}$ & 22 & 26 & 10 & 56 & 40 & 154 & 26.4 \\
\hline 10 & $\begin{array}{l}\text { Information Technology is the use of inter-organizational } \\
\text { systems that are used for information sharing and/or } \\
\text { processing across organizational boundaries }\end{array}$ & 19 & 15 & 21 & 62 & 37 & 154 & 25.3 \\
\hline 11 & $\begin{array}{l}\text { Increasingly, businesses have become digitally connected } \\
\text { including our customers }\end{array}$ & 34 & 37 & 15 & 38 & 30 & 154 & 31.3 \\
\hline 12 & $\begin{array}{l}\text { The instant delivery of the information through internet } \\
\text { elicits immediate response and action from the customer. }\end{array}$ & 43 & 31 & 3 & 33 & 44 & 154 & 30.5 \\
\hline
\end{tabular}

Table 2: Distribution of Responses

Source; Field Data, 2020

\subsection{Test of Hypothesis}

\begin{tabular}{|c|c|c|c|}
\hline \multicolumn{4}{|c|}{ Descriptive Statistics } \\
\hline & Mean & Std. deviation & $\mathrm{N}$ \\
\hline $\begin{array}{c}\text { Information Technology (IT) } \\
\text { GSCM }\end{array}$ & $\begin{array}{l}30.85 \\
26.25 \\
\end{array}$ & $\begin{array}{l}3.57 \\
4.05\end{array}$ & $\begin{array}{l}6 \\
6 \\
\end{array}$ \\
\hline \multicolumn{4}{|c|}{ Correlations } \\
\hline & & & GSCM \\
\hline $\begin{array}{c}\text { I T: Pearson correlation } \\
\text { Sig. (2- tailed) } \\
\text { N }\end{array}$ & & & $\begin{array}{c}-.503 \\
.309 \\
6\end{array}$ \\
\hline $\begin{array}{c}\text { GSCM.: Pearson correlation } \\
\text { Sig. }(2-\text { tailed }) \\
\mathrm{N}\end{array}$ & & & $\begin{array}{l}1 \\
6\end{array}$ \\
\hline
\end{tabular}

Table 3: Correlation Result

Spss Version 23

Correlation Is Significant at 0.05 Levels (2 Tailed)

\section{Discussion of Findings}

Information Technology acts as a major driver of Global Supply Chain Management. Starting from the suppliers, manufacturers, distributors, retailers to customers, it reduces lead time, paperwork and other unnecessary activities. It continuously supports the collaboration and coordination of supply chain through information sharing. It acts as a decision support system for taking analytical and managerial decisions.

The study also found that Information Technology have the following objectives of providing information, enabling single point of contact of data and allowing decisions based on total supply chain information. 
The findings revealed that Information Technology have a significant impact on global Supply Chain Management with a correlation coefficient of -. 503 and p-value of .309.The result obtained from the findings indicated that Information Technology correlates with global Supply Chain Management in South East Nigeria. This implies that Information Technology has stimulated global supply chain in the region studied.

\section{Conclusion}

In the modern era of Information Technology, firms look forward to increase their efficiencies and performances. SCM is one of the major tools that play a vital role in enhancing organizational efficiency in this world of new technology. The researcher concluded that it is practically impossible to effectively and efficiently achieve global supply chain management without Information Technology. IT has become the major driver and practical tool for managing global supply chain. IT as the key supply chain driver serves as the glue that allows other drivers to work together with the goal of creating an integrated, coordinated supply chain. The organizations need to be connected and become able to share information in real time and instantaneously in order to strategically fit into the global arena

\section{Recommendations}

The researcher recommended that

- Global companies should contribute their quota to global supply chain management by beingICT compliant.

- Companies all over the world should endeavor to equip their businesses with ICT facilities so as to enhance interorganizational relationship.

\section{References}

i. Akhadian. S.H (2015) Roles of information technology in supply chain management, Georgia Southern University.

ii. Beamon, B.M. (1999) Measuring supply chain Performance. International Journal of Operations \& Production

iii. Management.

iv. Chiappe.I.S. and Herrero V.A (1997) 'The status of SCM in Argentina Food Industry'. The International Journal of logistics Management.

v. Dwivedi, A. and Butcher, T (2009) SCM and Knowledge Management.

vi. Ettlie, J. E. and Reza, E. M. (1992) Organisational Integration and process innovation. Academy of Management Journal.

vii. Fasanghari, R.and Kamal, C. (2008) Assessing the impact of IT on SCM.

viii. Ford, D and Mouzas, S. (2010) Networking under uncertainty: Concepts and research agenda.

ix. Industrial Marketing Management.

x. Fraza, V. (2000) SCM for small distributors. Industrial Distribution.

xi. Handifield. R. and Nicholas. E. I (2002) 'Supply Chain Redesign' Pearson Education, New Delhi.

xii. Humphreys.P., Lai M. and Sculli D, (2001) An Inter-organizational Information System for SCM. International

xiii. Journal of Production Economics.

xiv. Hung, H.(2010) Reconciling the paradox of Supply -Side and Demand- Side Strategies in industrial Innovation.

xv. Industrial Marketing Management.

xvi. http://en.m.wikipedia.org>wiki>Globa...

xvii. Kurate, H and Nam, S. H. (2010) After- Sales service competition in a Supply Chain: Optimization of customer satisfaction level or profit or both? International Journal of Production Economics.

xviii. Lalonde, B.J. (1996) 'Issues in Supply Chain Costing' The international Journal Logistic management.

xix. Tim. F, (2007) into the depths of the I.E.I framework using the internet to create value in supply-chain Relationships in supply chain Management.

xx. Milgate, M. (2001) Supply Chain Complexity and delivery performance. SCM: An international Journal.

xxi. Paulraj, A. and Chen, I. J. (2007) Environmental Uncertainty and Strategic Supply Management:

xxii. A Resource Dependence Perspective and Performance implications. Journal of SCM.

xxiii. Quesada, H. and Meneses .M, (2010) Determination de un Modelo de Negocias para Apoyar el Desarrollo dela Pequena y Mediana Empresa Basado en casos de Exito. Costa Rica: Instituto Tecnologico de Costa Rica

xxiv. Rahul, A. (2005) SCM - Concept and Cases, Prentice Hall India Pvt Ltd, New Delhi

xxv. SCM Globe,blogscmglobe.com/?P=422

xxvi. Simchi -Levi; D, Kaminsky, P. and Simchi - Levi E (2003) Managing the supply chain, New York: McGraw Hill.

xxvii. Stevens, G. C. (1990) Successful SCM: Management Decision.

xxviii. Sunil, C. and Peter, M. (2005) SCM, Pearson Education New Delhi.

xxix. Turner, J. R. (1993) Integrated SCM: What's wrong with this picture? Industrial Engineering.

xxx. Wowak, K.D. Craighead C.W., Ketchen, D.J and Hult G.M (2013) supply chain knowledge and performance: a meta - analysis. Decision Sciences. 